\title{
PENYULUHAN MEMANFAATKAN KOMBINASI PROBIOTIK DAN EMPON-EMPON SEBAGAI IMUNOSTIMULAN SELAMA PANDEMI COVID-19
}

\section{COUNSELING UTILIZES THE COMBINATION OF PROBIOTICS AND EMMPONS AS IMMUNOSTIMULATES DURING THE COVID-19 PANDEMIC}

\author{
Iwan Sahrial Hamid ${ }^{1}$, Faisal Fikri ${ }^{2}$, Muhammad Thohawi Elziyad Purnama ${ }^{3}$ \\ ${ }^{1,2,3}$ Fakultas Kedokteran Hewan, Universitas Airlangga, Kampus C UNAIR J1. Ir. \\ Soekarno Mulyorejo Surabaya, 60115 \\ email: iwan-s-h@fkh.unair.ac.id
}

\begin{abstract}
abstret
The spread of the corona virus pandemic from the COVID-19 disease is increasingly massive. Until now, the confirmed cases in Indonesia have exceeded 100,000, with a case fatality rate of 8.9\%. In addition, there are 50 out of 100 districts / cities that have the highest risk of spreading with 49 percent. Some of the 50 regencies / cities are on the island of Java. Empon-empon does not only function to treat disease. However, the empon-empon also functions to maintain health and increase endurance. In the midst of the corona outbreak, we need to maintain our immune system. Empon-empon usually includes turmeric, ginger, galangal, ginger, kencur, and others. Community service activities aimed at the academic community of the Faculty of Veterinary Medicine, Airlangga University. Activities carried out through the stages of counseling, independent practice, and distribution of empon-empon combination probiotics. The results obtained from the pre and post test evaluation showed an increase in affective from $20 \%$ to $60 \%$, cognitive from $28 \%$ to $75 \%$, and psychomotor from $8 \%$ to $80 \%$.
\end{abstract}

Keywords: probiotics, empon-empon, COVID-19, Airlangga University

\section{abstrak}

Penyebaran pandemi virus corona dari penyakit COVID-19 kian masif. Hingga kini, kasus terkonfirmasi di Indonesia sudah melebihi angka 100.000, dengan tingkat kematian (case fatality rate) sebesar $8.9 \%$. Selain itu, terdapat 50 dari 100 kabupaten/kota yang memiliki risiko penyebaran tertinggi dengan 49 persen. Beberapa di antara $50 \mathrm{kabupaten} / \mathrm{kota}$ itu berada di Pulau Jawa. Empon-empon bukan hanya berfungsi untuk mengobati penyakit. Namun empon-empon juga berfungsi untuk menjaga kesehatan dan meningkatkan daya tahan tubuh. Di tengah maraknya wabah corona, kita perlu untuk menjaga daya tahan tubuh. Empon-empon biasa terdapat kunyit, jahe, lengkuas, temulawak, kencur, dan lainnya. Kegiatan pengabdian masyarakat dengan sasaran civitas akademika Fakultas Kedokteran Hewan Universitas Airlangga. Kegiatan dilaksanakan melalui tahapan penyuluhan, praktik mandiri, dan pembagian probiotik kombinasi empon-empon. Hasil yang didapatkan dari evaluasi pre dan post test terdapat peningkatan afektif dari $20 \%$ menjadi $60 \%$, kognitif dari $28 \%$ menjadi $75 \%$, dan psikomotor dari $8 \%$ menjadi $80 \%$.

Kata kunci: probiotik, empon-empon, COVID-19, Universitas Airlangga

\section{Pendahuluan}

Coronavirus adalah kumpulan virus yang bisa menginfeksi sistem pernapasan. Pada banyak kasus, virus ini hanya menyebabkan infeksi pernapasan ringan, seperti flu. Namun, virus ini juga bisa menyebabkan infeksi pernapasan berat, seperti infeksi paru-paru (pneumonia), Middle-East Respiratory Syndrome (MERS), dan Severe Acute 
Respiratory Syndrome (SARS)( Gugus Tugas Percepatan Penanganan COVID-19; World Health Organization. 2020).

Gejala awal infeksi virus Corona atau COVID-19 bisa berupa gejala flu, seperti demam, pilek, batuk kering, sakit tenggorokan, dan sakit kepala. Setelah itu, gejala bisa memberat. Pasien bisa mengalam demam tinggi, batuk berdahak bahkan berdarah, sesak napas, dan nyeri dada. Gejala-gejala tersebut muncul ketika tubuh bereaksi melawan virus Corona. Namun, secara umum ada 3 gejala umum yang bisa menandakan seseorang terinfeksi virus Corona, yaitu: demam (suhu tubuh di atas 38 derajat Celsius), batuk kering disertai merejan, sesak napas. Menurut penelitian, gejala COVID-19 muncul dalam waktu 2 hari sampai 2 minggu setelah terpapar virus Corona (Bai dkk. 2020).

Fokus pengabdian masyarakat Program Studi Pendidikan Dokter Hewan adalah untuk mengenalkan masyarakat tentang pengetahuan dan teknologi di bidang pengolahan bahan alam dan mikroba non pathogen untuk meningkatkan imunitas tubuh selama pandemic CODIV-19.

Indonesia merupakan salah satu negara penghasil jahe (Zingiber officinale Rosc) terbesar di dunia. Jumlah produksi jahe di Indonesia meningkat dari tahun ke tahun. Pada tahun 2003, produksi jahe nasional adalah sebesar 112.290 ton. Dengan tingkat kenaikan produksi sebesar 3,28 \% tiap tahun maka pada tahun 2009 jumlah produksi jahe di Indonesia diperkirakan sebesar $136.388,1$ ton. Jumlah jahe yang melimpah ini justru menimbulkan permasalahan tersendiri yaitu turunnya nilai ekonomi jahe. Selain itu teknologi pasca panen yang tidak tepat menyebabkan jumlah jahe yang membusuk juga besar karena tidak termanfaatkan secara optimal (Utami, dkk. 2017).

Empon-empon memiliki kandungan aktif yaitu oleoresin dan salah satu teknologi pengolahannya adalah dengan dibuat sebagai sediaan/minuman instan yang siap dikonsumsi (siap saji) dengan penambahan air hangat atau air panas. Penelitian ini bertujuan untuk membuat rancangan proses dan analisis tingkat kelayakan finansial produksi minuman instan empon-empon (Pamadyo \& Mujahid 2014).

Kegunaan ekstrak jahe antara lain yaitu sebagai obat sakit kepala, obat batuk, masuk angin, untuk mengobati gangguan pada saluran pencernaan, stimulansia, diuretik, rematik, menghilangkan rasa sakit, obat antimual dan mabuk perjalanan, karminatif (mengeluarkan gas dari perut), kolera, diare, sakit tenggorokan, difteria, neuropati, sebagai penawar racun dan sebagai obat luar untuk mengobati gatal digigit serangga, keseleo, bengkak, serta memar. Banyaknya kegunaan ekstrak jahe merupakan sebuah peluang yang sangat baik untuk dikembangkan (Gusdiantoro 2019).

Jahe mengandung oleoresin yang banyak dimanfaatkan dalam industri farmasi dan makanan. Meningkatnya kebutuhan oleoresin ini merupakan salah satu peluang untuk meningkatkan nilai ekonomi jahe yaitu dengan mengambil ekstrak oleoresin jahe. Salah satu teknologi pengolahan oleoresin jahe adalah dengan dibuat sebagai sediaan/minuman instan. Sediaan instan adalah suatu sediaan yang siap dikonsumsi (siap saji) dengan penambahan air hangat atau air panas dan penambahan satu atau lebih bahan tambahan, sehingga sediaan instan lebih disukai oleh masyarakat dan rasanya juga lebih enak. Adapun kekurangannya adalah memerlukan waktu cukup lama, pemanasan yang tinggi 
Iwan Sahrial Hamid dkk.: Penyuluhan Memanfaatkan Kombinasi Probiotik dan Empon-Empon Sebagai Imunostimulan Selama Pandemi Covid-19

dan penguapan yang lama dalam formulasinya sehingga zat-zat yang tidak tahan terhadap pemanasan akan menguap atau hilang (Suparman \& Saptarini, 2019).

Probiotik dapat didefinisikan sebagai suplemen makanan yang mengandung mikrobial hidup menimbulkan efek menguntungkan hewan sebagai induk semangnya melalui peningkatan keseimbangan mikroflora di dalam saluran pencernaan. Kelompok bakteri yang dimaksud adalah Lactobacillus acidophylus, Bifidobacterium bifidum, Bifidobacterium pseudolongum dan Streptococcus faecalis. Bakteri tersebut diharapkan dapat meningkatkan pencernaan menjadi lebih baik (Klayraung, dkk. 2009).

Telah dilakukan penelitian oleh Gilliland, 2004 dengan menggunakan probiotik yang mengandung kultur bakteri Lactobacillus acidophylus, Bifidobacterium pseudolongum dan Streptococcus faecalis, bahwa bakteri tersebut dapat meningkatkan zat nutrisi oleh enzim yang dihasilkan dalam saluran cerna melalui peningkatan daya cerna (Gilliland 2004).

\section{METODE PENGABDIAN MASYARAKAT}

Dalam kegiatan Pengabdian Kepada Masyarakat ini akan dilakukan kepada sekitar 120 orang mitra sivitas akademik Fakultas Kedokteran Hewan Universitas Airlangga. Metode yang digunakan dalam pelaksanaan kegiatan pengabdian kepada masyarakat ini dilakukan dalam lima tahap kegiatan meliputi:

\section{Orientasi Lokasi Sasaran}

Orientasi lokasi dilakukan sebelumnya berdasarkan factor risiko terbesar yang sesuai wilayah terdampak COVID-19. Orientasi juga didasarkan dari sumber sekunder data website resmi penanganan COVID-19 Provinsi Jawa Timur.

\section{Pendidikan dalam Bentuk Penyuluhan}

Tambahan pengetahuan tentang pengolahan tanaman empon-empon dan cara menggunakan probiotik dilakukan berupa pemberian penyuluhan. Penyuluhan dilakukan sebanyak dua kali, yang menjadi sasaran adalah sivitas akademik Fakultas Kedokteran Hewan Universitas Airlangga. Materi yang diberikan meliputi: Penggunaan obat dan vitamin, Pengetahuan tentang penyakit COVID-19 dan pencegahannya dan Probiotik beserta aplikasinya

Pelaksanaan seminar diselenggarakan di Fakultas Kedokteran Hewan dan memenuhi kriteria dapat berperan aktif mengikuti setiap tahapan kegiatan pengabdian pada masyarakat. Bentuk penyuluhan dilakukan dengan menggunakan media proyektor in focus dan setiap peserta mendapat seperangkat alat tulis berupa note book, ballpoint dan makalah. Penyuluhan dilakukan selama dua jam dan diakhiri dengan diskusi atau tanya jawab selama satu jam.

\section{Pelatihan}

Hasil penyuluhan yang telah diberikan pada masyarakat perlu ditindak lanjuti dengan pemberian pelatihan guna meningkatkan ketrampilan dan kemampuan dalam mengolahan tanaman empon-empon dan probiotik. Pelatihan yang diberikan meliputi: 
Persiapan bahan tanaman empon-empon, Cara pengolahan dan membuat sediaan minuman empon-empon, Cara membuat minuman probiotik

\section{Pelayanan}

Konsep pengabdian masyarakat dengan penerapan teknologi hasil penelitian yang dilakukan perguruan tinggi tentunya berujung pada pola pelayanan masyarakat. Tercapainya penerapan ilmu pengetahuan dan teknologi di tengah masyarakat membuktikan bahwa karya yang dihasilkan perguruan tinggi memberikan andil dalam kemajuan pembangunan bangsa. Pelayanan pada masyarakat yang dilaksanakan oleh tim pengabdian masyarakat dimulai dari kepedulian akan kemajuan dan peningkatan taraf hidup kesejahteraan masyarakat dalam mencegah penularan COVID-19. Sarana yang disediakan untuk menunjang kelangsungan program adalah Paket Probiotik yang merupakan produk PT. Centra Biotech Indonesia, Klaten Jawa Tengah.

\section{Rancangan Evaluasi}

Evaluasi pelaksanaan program pengabdian Kepada Masyarakat ini dilakukan dengan:

1. Dilakukan kuisioner kepada peserta sebelum dan sesudah dilaksanakaan tahap pembinaan, sebagai evaluasi tahap awal untuk mengetahui pengetahuan peserta mengenai khasiat produk probiotik;

2. Diskusi mengenai upaya pencegahan COVID-19 melalui peningkatan imunitas tubuh dengan mengkonsumsi tanaman empon-empon.

\section{HASIL DAN PEMBAHASAN}

Kegiatan dilaksanakan selama 2 hari yakni rabu dan kamis. Hari pertama dilakukan sosialisasi awal bersama mitra dengan topic pembuatan probiotik kombinasi empon-empon. Hari kedua dilakukan praktik pembuatan, diskusi cara pemakaian dan khasiat untuk meningkatkan imunitas selama pandemi. Mitra adalah seluruh civitas akademika Fakultas Kedokteran Hewan baik yang mendapat jadwal Work From Office (WFO) dan Work From Home (WFH) total keseluruhan 125 orang. Skema pembagian produk probiotik juga dibagikan dan dipaketkan ke rumah masing-masing.

Kegiatan pengabdian kepada masyarakat yang telah dilakukan meliputi pembagian probiotik kombinasi empon-empon. Kemudian dijelaskan secara langsung tentang produk probiotik yang diberikan meliputi: definisi dan isi produk probiotik kombinasi empon-empon, cara pemberian (dosis, aplikasinya dan penyimpanannya), dan pengaruh dan khasiat yang dihasilkan terhadap imunitas. dengan:

Evaluasi pelaksanaan program pengabdian Kepada Masyarakat ini dilakukan

1. Dilakukan pre dan post tes materi penyuluhan kepada peserta sebelum dan sesudah dilaksanakaan tahap pembinaan, sebagai evaluasi tahap awal untuk mengetahui pengetahuan peserta mengenai produk;

2. Kuisioner untuk mengetahui umpan balik tentang pengabdian masyarakat yang telah dilaksanakan;

3. Pembuktian tentang manfaat probiotik dalam peningkatan imunitas. 
Pre test diberikan sebelum peserta mendapat materi penyuluhan dari penyuluh sedangkan post test diberikan setelah peserta mendapat materi penyuluhan dari penyuluh. Pretest dan post test berisikan soal-soal mengenai Covid-19, probiotik dan kegunaannya yang bertujuan untuk mengetahui seberapa jauh peserta penyuluhan dapat menyerap materi yang diberikan oleh penyuluh. Soal pre test dan post test ini berisi soal yang sama. Berikut di bawah ini merupakan hasil evaluasi yang telah dihimpun oleh tim pengabdian masyarakat:

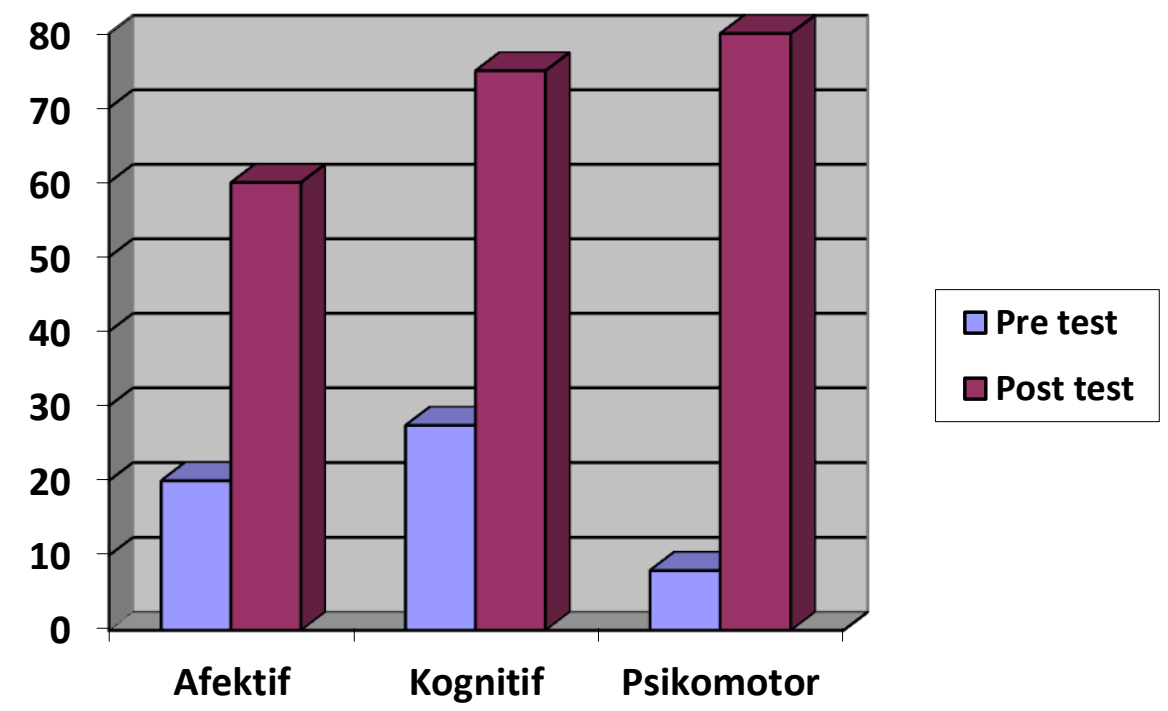

Gambar 1. Evaluasi hasil pre dan post test

Aspek afektif yang diuji meliputi pengetahuan pengertian, fungsi, komposisi bahan, dan penggunaan probiotik. Aspek kognitif yang diuji meliputi pemahaman waktu penggunaan dan formula probiotik. Aspek psikomotor yang diuji meliputi keterampilan dan skill dalam menggunakan probiotik. Untuk menjaga keberlanjutan program, kader telah dibentuk yang juga merupakan civitas akademik sehingga selama pelaksanakan program dapat terpantau hingga dapat mengaplikasikan pengolahan probiotik secara mandiri.

Program Pengabdian Kepada Masyarakat ini secara umum mempunyai target untuk meningkatkan pengetahuan para sivitas akademika Universitas Airlangga agar dapat memanfaatkan pengolahan tanaman empon-empon sebagai minuman imunomodulator. Selain itu dengan tambahan probiotik sebagai suplemen untuk meningkatkan sistem pencernaan makanan.

Kualitas minuman serbuk instan ini mengacu pada standar mutu SNI 01-4320-1996 tentang syarat mutu serbuk minuman tradisional. SNI tersebut mensyaratkan warna, bau, dan rasa yang normal, kadar air maksimal 3\%, kadar abu maksimal $1,5 \%$, jumlah gula minimal $85 \%$ dan syarat mutu yang lain. Proses utama pembuatan minuman instan ekstrak jahe meliputi beberapa proses, yaitu pemisahan dan pemurnian ekstrak jahe. Pembuatan minuman instan jahe diawali dengan pemisahan ekstrak yang dilakukan dengan proses ekstraksi yaitu menghancurkan bahan hingga ukuran tertentu kemudian memisahkan ekstrak dari campurannya. Proses pemurnian 
ekstrak jahe dilakukan dengan cara mengendapkan ekstrak jahe secara alami dari partikel-partikel atau padatan yang ada secara terpisah hingga waktu tertentu ke dalam suatu wadah. Perlakuan ini bertujuan untuk memisahkan cairan ekstrak jahe dengan partikel-partikel atau padatan yang ada. Padatan tersebut mempunyai berat jenis yang lebih besar dari berat jenis air sehingga akan mengendap di bawah permukaan wadah. Hasil yang diharapkan adalah mitra dapat menerapkan pengolahan tanaman empon empon dalam bentuk cairan ekstrak yang lebih homogeny dan jernih untuk diolah lanjut menjadi minuman serbuk instan (Koswara 2006).

Indonesia saat ini merupakan laboratorium penyakit terlengkap, berbagai penyakit muncul ke permukaan, mulai dari penyakit infeksi, penyakit degeneratif dan penyakit baru semacam campak Jerman, sindrom pernafasan akut parah (SARS-1). Kesehatan merupakan unsur utama pembangunan sumber daya manusia (SDM), dan sudah saatnya pembangunan dilihat dari kualitas SDMnya. Kesehatan masyarakat tidak hanya terdiri dari pengobatan penyakit yang dilakukan dalam waktu singkat tetapi juga upaya kesehatan jangka menengah dan jangka panjang. Salah satu bidang baru dalam farmakologi yang masih dalam tingkat eksplorasi dan perdebatan adalah Imunomodulator (Immunomodulating agents) yaitu mengembangkan bahan-bahan yang dapat meningkatkan respon imunitas daripada menekannya, atau dengan kata lain imunomodulator adalah bahan (obat) yang dapat mengembalikan ketidakseimbangan sistem imun. Cara kerja imunomodulator meliputi: 1) mengembalikan fungsi sistem imun yang terganggu (imunrestorasi), 2) memperbaiki fungsi sitem imun (imunostimulasi) dan 3) menekan respons imun (imunosupresi) (Suhirman \& Winarti 2010).

Imunomodulator digunakan terutama pada penyakit imunodefisiensi, infeksi kronis dan kanker. Pemberian imunostimulan atau imunomodulator sangat diperlukan untuk mencegah penghancuran sel penolong CD4+ pada pasien AIDS dan kanker. Dalam ilmu kedokteran, imunitas pada mulanya berarti resistensi relatif terhadap suatu mikroorganisme. Resistensi terbentuk berdasarkan respon imunologik. Selain membentuk resistensi terhadap suatu infeksi, respon imun juga dapat mengakibatkan terjadinya berbagai penyakit. Oleh karena itu pada masa sekarang ini arti respon imun sudah lebih luas, yang pada dasarnya mencakup pengobatan maupun pencegahan suatu penyakit yang disebabkan oleh pengaruh faktor dari luar tubuh atau zat asing. Aktivitas sistem imun dapat menurun karena berbagai faktor, diantaranya karena usia atau penyakit (Fatoni 2016).

Adanya senyawa-senyawa kimia yang dapat meningkatkan aktivitas sistem imun sangat membantu untuk mengatasi penurunan sistem imun dan senyawa-senyawa tersebut dapat diperoleh dari tumbuh-tumbuhan. Saat ini terdapat beberapa jenis tumbuhan yang dideteksi berkhasiat sebagai imunomodulator, antara lain: Echinacea angustifolia, Andrographis paniculata, Plantago major, Allium sativum, Zingiber officinalis, Curcuma xanthorriza. Empon-empon atau temu-temuan (Zingiberaceae) merupakan rempah dan bahan obat tradisional yang penting bagi bangsa Indonesia dan telah menjadi bagian dari budaya bangsa. Oleh karena itu perlu diperhatikan dan dikembangkan serta digali potensinya sehingga memberikan nilai tambah dan dapat meningkatkan nilai jualnya baik dipasar domestik maupun global. Ekspor jahe Indonesia setiap tahunnya sekitar 2 $4 \%$ kebutuhan dunia sedang kebutuhan dalam negeri juga tidak sedikit (Sumarni 2017). 
Iwan Sahrial Hamid dkk.: Penyuluhan Memanfaatkan Kombinasi Probiotik dan Empon-Empon Sebagai Imunostimulan Selama Pandemi Covid-19

Kegiatan pengabdian kepada masyarakat yang telah dilakukan meliputi pemberian probiotik untuk minuman yang diberikan secara langsung kepada mitra melalui seminar. Kemudian dijelaskan secara langsung tentang produk probiotik yang diberikan meliputi : Definisi probiotik, Isi produk yang ada di probiotik, Kegunaan menggunakan probiotik, Cara pemberian (dosis, aplikasinya dan penyimpanannya), Biaya tambahan yang dibutuhkan untuk memperoleh probiotik.

Air kelapa muda merupakan hasil samping (by-product) dari buah kelapa dengan total produksi di Indonesia sebesar 3.75 ton/tahun. Tingginya angka produksi tersebut sayangnya tidak diikuti dengan pengembangan produk secara maksimal. Dalam bidang bioteknologi, air kelapa muda memiliki potensi untuk dikembangkan sebagai media fermentasi. Air kelapa muda kaya akan nutrisi seperti gula, protein dan lemak yang relatif lengkap sehingga sangat baik untuk menunjang pertumbuhan bakteri penghasil produk pangan. Salah satu komponen nutrisi terpenting dalam air kelapa muda adalah gula. Air kelapa muda mengandung karbohidrat dalam bentuk sederhana seperti glukosa dan fruktosa yang dapat berperan sebagai fermentable sugar dan dapat menjadi sumber karbon bagi mikroorganisme. Kandungan lain dalam air kelapa muda adalah mineral seperti kalsium dan fosfor yang berperan sebagai sumber elektrolit alami (Purwandhani, dkk. 2007).

Penggunaan air kelapa muda sebagai media fermentasi salah satunya berupa produk yang disebut sebagai minuman probiotik. Minuman probiotik adalah istilah lain untuk menyebutkan minuman fermentasi asam laktat yang mengandung bakteri asam laktat hidup dan dapat memberikan efek kesehatan ketika dikonsumsi. Pembuatan minuman probiotik air kelapa muda memanfaatkan BAL (bakteri asam laktat) Lactobacillus casei strain Shirota yang diharapkan mampu memenuhi kebutuhan probiotik hidup sekaligus menjadi sumber elektrolit ketika dikonsumsi. Pertumbuhan BAL probiotik selama fermentasi perlu diperhatikan untuk memperoleh jumlah bakteri yang mencukupi sehingga dapat disebut sebagai produk probiotik. Penelitian ini melibatkan dua faktor yang dapat menentukan kualitas mikrobiologi produk yaitu konsentrasi sukrosa dan lama fermentasi. Konsentrasi sukrosa yang digunakan harus dalam jumlah yang tepat sehingga mampu menunjang pertumbuhan bakteri. Sementara lama fermentasi akan menentukan kemampuan bakteri memecah nutrisi di dalam medium secara optimal. Penambahan konsentrasi sukrosa dan lama fermentasi yang berbeda juga akan mempengaruhi sifat fisik, kimia, dan organoleptik dari produk yang dihasilkan (Muharani 2011).

Secara pathogenesis infeksi ini akan menyebabkan kondisi limfopenia yang parah dan lama karena penurunan sel CD4) dan menyebabkan kematian pada anak anjing (Eguchi, dkk. 2019). Probiotik adalah mikroorganisme hidup bermanfaat yang memberi manfaat kepada tubuh. Spesies Lactobacilluss adalah probiotik yang sudah pernah diteliti, dengan efek fisiologis dan imunologisnya seperti regulasi aktivitas sel $\mathrm{T}$ (NK), mencegah infeksi virus infuenza pada hewan coba dan meningkatkan kadar interferon- $\gamma$ (IFN- $\gamma$ ) (Borchers, dkk. 2009). Lactobacillus acidophilus dapat meningkatkan regulasi gen anti-virus melalui jalur reseptor Toll-like, mampu tahan asam empedu, meningkatkan fisiologis lingkungan usus dan mencegah obesitas. Probiotik sebagai suplemen makanan yang mengandung mikrobial hidup menimbulkan efek menguntungkan hewan sebagai induk semangnya melalui peningkatan keseimbangan mikroflora di dalam saluran pencernaan. Kelompok bakteri yang dimaksud adalah Lactobacillus acidophylus, 
Bifidobacterium bifidum, Bifidobacterium pseudolongum dan Streptococcus faecalis. Bakteri tersebut merupakan bakteri asam laktat yang mempunyai kemampuan menghasilkan laktase untuk mencerna laktosa dan juga menstimulasi enzim proteolitik dan selulolitik, sehingga hasil akhir terjadi peningkatan serapan nutrient (Cutting 2011).

Suatu penelitian eksperimental menunjukan bahwa probiotik bisa digunakan untuk mengontrol mokroorganisme yang mengkontaminasi makanan, secara selektif mikroorganisme pada probiotik dapat mengurangi diare idiopathik pada kalkun, juga mengurangi koloni salmonella pada kalkun dan broiler (Borchers, dkk. 2009). Mikroba asam laktat adalah sekelompok bakteri yang tidak membentuk spora, bersifat gram positip, memproduksi asam laktat sebagai produk akhir yang pada umumnya adalah bakteri baik (non patogen). Bakteri asam laktat ini dikenal sebagai Probiotik. Organisme yang tergolong bakteri asam laktat ini adalah Lactobacillus, Pediococcus, Bifidobacterium dan Streptococcus. Probiotik yang paling banyak digunakan adalah tergolong dalam kelompok Lactobacillus seperti L. casei, L.acidophillus, L. rhamnosus dan kelompok Bifidobacterium seperti B. bifidum, B. longum, B. Breve (Eguchi, dkk. 2019).

\section{PENUTUP}

\section{Simpulan}

Dapat disimpulkan dari kegiatan ini terdapat peningkatan afektif dari $20 \%$ menjadi $60 \%$, kognitif dari $28 \%$ menjadi $75 \%$, dan psikomotor dari $8 \%$ menjadi $80 \%$. Kader yang terbentuk akan dipantau sehingga pengendalian Covid-19 di lingkungan FKH Unair dapat ditingkatkan selama masa adaptasi kebiasaan baru.

\section{DAFTAR PUSTAKA}

Bai, Y., Yao, L., Wei, T., Tian, F., Jin, D. Y., Chen, L., \& Wang, M. (2020). Presumed asymptomatic carrier transmission of COVID-19. Jama.

Borchers, A. T., Selmi, C., Meyers, F. J., Keen, C. L., \& Gershwin, M. E. (2009). Probiotics and immunity. Journal of gastroenterology, 44(1), 26-46.

Cutting, S. M. (2011). Bacillus probiotics. Food microbiology, 28(2), 214-220.

Eguchi, K., Fujitani, N., Nakagawa, H., \& Miyazaki, T. (2019). Prevention of respiratory syncytial virus infection with probiotic lactic acid bacterium Lactobacillus gasseri SBT2055. Scientific reports, 9(1), 1-11.

Fatoni, A. (2016). Efek Imunomodulator Jus Herbal Kombinasi Bawang Putih, Jahe Merah, Jeruk Nipis, Cuka Apel Dan Madu Terhadap Mencit Putih Jantan. Jurnal Ilmiah Bakti Farmasi, 1(2), 59-66.

Gilliland, S., 2004. Probiotics provide benefits for livestock. High Plains / Midwest AG Journal. food microbiologist for the Oklahoma Food and Agricultural Products Research and Technology Center.

Gugus Tugas Percepatan Penanganan COVID-19. www.covid19.go.id 
Iwan Sahrial Hamid dkk.: Penyuluhan Memanfaatkan Kombinasi Probiotik dan Empon-Empon Sebagai Imunostimulan Selama Pandemi Covid-19

Gusdiantoro, H. (2019). Pengaruh Perbandingan Jahe Dan Kayu Manis Serta Jenis Gula Terhadap Karakteristik Minuman Herbal (Doctoral dissertation, Universitas Pasundan).

Jatim Tanggap COVID-19. infocovid19.jatimprov.go.id

Klayraung, S., Viernstein, H., \& Okonogi, S. (2009). Development of tablets containing probiotics: Effects of formulation and processing parameters on bacterial viability. International Journal of Pharmaceutics, 370(1-2), 54-60.

Koswara, S. (2006). Jahe, rimpang dengan sejuta khasiat. Jakarta: Pustaka Sinar Harapan.

Muharani, M. (2011). Perkembangan Bakteri Probiotik Dan Nilai Organoleptik Minuman Fermentasi Dari Media Nira Aren (Arenga Pinnata Merr), Nira Tebu (Saccharum Officinarum L.) Dan Air Kelapa (Cocos nucifera L.) (Doctoral dissertation, Universitas Andalas).

Pamadyo, S., \& Mujahid, R. (2014). Uji Klinik Ramuan Jamu Imunostimulan Terhadap Fungsi Ginjal Dan Fungsi Hati. JIFFK: Jurnal Ilmu Farmasi dan Farmasi Klinik, 17-20.

Purwandhani, S. N., Suladra, M., \& Rahayu, E. S. (2007). Stabilitas Thermal Agensia Probiotik L. acidophillus SNP 2 Terenkapsulasi Metode Ekstrusi dan Emulsi. In Seminar Nasional Teknologi (pp. 1-6).

Suhirman, S., \& Winarti, C. (2010). Prospek dan fungsi tanaman obat sebagai imunomodulator. Balai Penelitian Tanaman Obat dan Aromatik. hal, 121-131.

Sumarni, S. (2017). Pemberian Jahe (Zingiber Officinale) Dan Gula Merah Sebagai Imunomodulator Terhadap Gambaran Darah Ayam Broiler (Doctoral dissertation, UNIVERSITAS ANDALAS).

Suparman, A., \& Saptarini, N. M. (2019). Formulasi Tablet Imunostimulan Ekstrak Daun Pepaya, Herba Meniran, Dan Rimpang Kunyit. Farmaka, 17(2), 111-117.

Utami, W. S., Fatmawati, H., \& Hermansyah, B. (2017). Development of standardized herbal therapy of bangle extract (Zingiber Cassumunar Roxb.) on the expression of Icam-1 for complementary therapy to prevent complications in Malaria.

World Health Organization. (2020). Coronavirus disease 2019 (COVID-19): situation report, 67. 